\title{
Taking Stock of Social Sustainability and the U.S. Beef Industry
}

\author{
Hannah Gosnell *(1), Kelsey Emard and Elizabeth Hyde \\ College of Earth, Ocean, and Atmospheric Sciences, Oregon State University, Corvallis, OR 97331, USA; \\ kelsey.emard@oregonstate.edu (K.E.); hydeel@oregonstate.edu (E.H.) \\ * Correspondence: hannah.gosnell@oregonstate.edu
}

check for

updates

Citation: Gosnell, H.; Emard, K.; Hyde, E. Taking Stock of Social Sustainability and the U.S. Beef Industry. Sustainability 2021, 13, 11860. https://doi.org/10.3390/su132111860

Academic Editors: Leslie A. Duram and Giacomo Falcone

Received: 10 July 2021

Accepted: 21 October 2021

Published: 27 October 202

Publisher's Note: MDPI stays neutral with regard to jurisdictional claims in published maps and institutional affiliations.

Copyright: (c) 2021 by the authors. Licensee MDPI, Basel, Switzerland This article is an open access article distributed under the terms and conditions of the Creative Commons Attribution (CC BY) license (https:// creativecommons.org/licenses/by/ $4.0 /)$.

\begin{abstract}
This paper presents the results of a study of social sustainability in the U.S. beef industry with a focus on the pre-harvest, cattle ranching portion of the industry. Using an integrative literature review and interviews with fifteen thought leaders in the field, we synthesize key indicators of social sustainability and provide a framework to be used in analyzing social sustainability in the pre-harvest beef industry. We identify six themes that are critical to social sustainability: human health; learning/adaptation; community relations; equity and inclusion; land ownership, tenure, and succession; and industry structure. However, our results also indicate that social sustainability as a term is insufficient for representing the positive futures desired by ranchers and that quantifiable indicators and metrics are not able to capture some of the subjective qualities of social sustainability. There is a need for future research that builds on these ideas and explores alternative future scenarios for the U.S. beef industry by engaging more diverse perspectives.
\end{abstract}

Keywords: social sustainability; ranching; beef industry; social justice; community resilience

\section{Introduction}

A three-pillar conception of sustainability with a "triple bottom line" involving environmental, economic, and social considerations emerged from multiple sources in the 1980s and has become ubiquitous in sustainability work [1]. The 1992 United Nations Conference on Sustainable Development in Rio de Janeiro defined the social pillar to include concepts like "the right to live a decent life; inter-generational, intra-generational, and international social justice; and local participation in [sustainable development] processes" [2] (p. 217). The social dimension remains the least clearly conceived of the three pillars, and numerous studies have called for the development of clearer definitions and frameworks to analyze the social dimensions of sustainability [3-8]. Across multiple disciplines, work has emerged to clarify and frame social sustainability, with a considerable body of scholarship focusing on social sustainability and community resilience in the urban context [9-13]. Much less has been written on what social sustainability means and how to achieve it in rural, agrarian contexts. In response to a request from the National Cattlemen's Beef Association (NCBA), we conducted a study determining indicators of, and pathways and barriers to, social sustainability in the U.S. beef industry, focusing on the pre-harvest cattle ranching sector. The results of this study provide the first comprehensive assessment of scholarship and industry activity on the social aspects of sustainability in ranching and contribute to efforts to better define and apply the concept of social sustainability across the globe. Based on our analysis, we propose a framework for evaluating social sustainability in cattle ranching at three different scales: ranch, community, and industry.

The U.S. cattle and beef industry has long prided itself on meeting the needs of beef consumers worldwide by "producing a safe, affordable, and nutritious protein" [14]. Cattle production consistently accounts for the largest share of U.S. agricultural receipts, and there are over 700,000 cattle farms, ranches, and feedyards that support rural economies throughout the country $[15,16]$. With global population growth and rising income levels, demand for beef is increasing and expected to grow [16]. Responding to consumer health 
and safety concerns, the U.S. Department of Agriculture Food Safety Inspection Service partnered with leaders in the beef industry in 1982 to develop the Beef Quality Assurance program, which marked the beginning of decades of work within the industry to ensure a healthy and environmentally safe product, including a number of metrics and indicators to assess sustainability $[17,18]$. While most of this work has focused on environmental sustainability, there is growing interest in the economic and social impacts of beef production and the social sustainability of the U.S. beef industry.

While social sustainability remains a poorly defined concept, a few definitions circulating in the beef industry served as a base for our investigations of the topic, including the following: "socially sustainable communities are equitable, diverse, connected and democratic and provide a good quality of life" [19] (p. 6), and social sustainability is "community and organizational resilience, based on principles such as equity, health, social capital, and well-being" [20] (para. 4). In conducting our study, we began from the premise that a socially sustainable beef industry would be one in which the beef industry created conditions of social well-being for all those impacted by it-ranchers, employees, consumers, and other stakeholders. Concern that the beef industry does not promote social well-being has been growing. For example, the COVID-19 pandemic resulted in a new level of media attention and scrutiny regarding the disproportionate impacts of the pandemic on meat packing plant workers, many of whom are members of underserved racial minority populations [21]. Further, national media attention has recently showcased conflict in agricultural communities, for example between ranchers and public land managers and between non-tribal ranchers and tribal members over resource access, as seen in articles in Reuters and the New York Times [22,23]. As this increased attention to the social aspects of the cattle and beef industry demonstrates, the beef industry's social license to operate will increasingly depend on its social sustainability efforts. Consumers and advocacy groups are questioning whether the beef industry can maintain and contribute to social well-being in the rural U.S., suggesting that a viable future for the industry must include practices that value and care for lives all along the supply chain.

The U.S. beef supply chain operates at multiple scales and across multiple regions. While social sustainability is critical in all these contexts, in this paper we focus primarily on the pre-harvest production of cattle and especially on cow-calf ranching operations. Cow-calf operations raise herds of mother cows to produce offspring that are typically transported elsewhere (feedlot or custom grazing operation) to be "finished" before slaughter. We examine social sustainability within pre-harvest production at three scales: the individual ranching operation, the ranching community, and the larger beef industry. Specifying these three interconnected scales allows us to probe how social life and relationships are valued and protected on ranches, within ranching communities, and more broadly through the structure of the national beef cattle industry. Of course, social sustainability is critical in the post-harvest processing, packaging, and distribution sector of the U.S. beef industry as well, and we do draw connections to this sector in this paper. However, the preand post-harvest sectors have unique social contexts, and due to the scarcity of work done on the pre-harvest sector, we have chosen to primarily focus on the pre-harvest/ranching portion of the beef industry.

In this paper, we review scholarly literature on the concept of social sustainability and its application to agricultural and specifically cattle ranching contexts. We then present the results of semi-structured interviews with fifteen thought leaders on socially sustainable approaches to beef production. We consider definitions, criteria, and indicators as well as barriers and pathways to social sustainability in beef production. Building on analyses from the literature and on insights from our key informants, we propose a qualitative framework for evaluating and improving social sustainability in the cow-calf sector of the beef industry that considers processes and activities at the three interconnected scales described above. Simultaneously we pose questions that need further contemplation including: Is the term sustainability adequate and useful for envisioning a truly beneficial beef industry? Are quantifiable metrics and indicators useful for considering and 
addressing social sustainability issues? What systemic changes need to happen for the beef industry to balance the three pillars of sustainability (environmental, economic, social)?

\section{Materials and Methods}

Research for this paper included an integrative literature review and semi-structured interviews. An integrative approach to assessing literature "reviews, critiques, and synthesizes representative literature on a topic in an integrated way such that new frameworks and perspectives on the topic are generated. The body of literature includes all studies that address related or identical hypotheses or research problems" [24].

We conducted our review using Web of Science and Google Scholar during winter 2021 with the goal of synthesizing representative literature in order to inform a new framework. We focused on analyses of, and efforts to define, social sustainability in the context of agriculture broadly and cattle ranching specifically. While there is a considerable amount of work done on social sustainability in agriculture, we focused on articles that sought to synthesize and identify metrics and indicators. We also searched for social sustainability as it relates to ranching, which has received far less attention. We found only three articles explicitly addressing social sustainability on cattle ranches. However, we also searched for articles that addressed terms represented in definitions of social sustainability as described in the introduction, namely community resilience, social justice, equity, health, and wellbeing in connection with cattle ranching, and this provided a greater breadth of articles to draw on. We also searched for sources in the bibliographies of key articles. This approach was narratively focused on the social aspects of cattle ranching and carefully structured to access a wider range of contributing literature than just those articles using the term social sustainability.

To supplement the findings of the literature review, in spring 2021 we conducted interviews with fifteen key informants. We selected interviewees through purposive sampling informed by the authors' knowledge of thought leaders on the subject of ranching and social sustainability, suggestions from our sponsors, and snowball sampling [25]. To participate, interviewees had to have worked in or around the cattle ranching industry in some capacity for at least fifteen years and be known or recommended to us as someone who had given the issue of social sustainability substantial thought.

Our interview sample has roughly equal representation by gender and region, with participants from across the U.S., Far West, Northwest, Southwest, Great Plains, and Southeast. Our sampling method facilitated access to key informants within a relatively small study scope who have extensive experience with the subject of our study. However, there are also some important limitations to our sampling method, including the small number, which is not meant to be statistically representative but rather to compliment the literature review in developing a preliminary framework for social sustainability that can be tested and evaluated in a more robust study of the beef industry in the future. An important limiting factor in our sample is the racial composition of interview subjects, who are all White. This lack of racial diversity reflects both the comparatively small number of non-White ranchers in the U.S., as well as the need for a more sustained effort to recruit ranchers of color as participants in rangeland social science studies [26]. We hope that future research will take the need for focused effort on recruiting participants of color seriously.

Informed by our literature review, interview questions asked how the interviewees define social sustainability and what indicators of social sustainability exist at the ranch, community, and industry scales. Topics explored included labor relations and employment; gender relations; community relations; land ownership; animal welfare; and human health, quality of life, and well-being. Interviewees were given the opportunity to comment on topics not covered in our interview guide, as well. We also asked for interviewees' insights into key barriers and pathways to social sustainability at all three scales. Interviews lasted from one to two hours and were recorded and transcribed. We used a thematic analysis approach with repeated coding, sorting, and categorizing to analyze the interviews. The 
coding resulted in the identification of key indicators, pathways, and barriers to social sustainability that emerged consistently from the qualitative data $[25,27]$. Quotes by interviewees included in this paper are attributed using a letter and number attribution system where $\mathrm{R}=$ rancher, $\mathrm{N}=\mathrm{NGO}$ personnel, and $\mathrm{A}=$ academic/writer. The numbers 1-15 represent the order in which the interviews were conducted. Thus, RN7 is a rancher and NGO employee and was the seventh interview we conducted. Table 1 shows interviewee demographics and the attribution system used in this paper.

Table 1. Interviewee demographics and attribution structure.

\begin{tabular}{ccccc}
\hline Attribution & $\begin{array}{c}\text { Beef Industry } \\
\text { Affiliation }\end{array}$ & Gender & Race/Ethnicity & $\begin{array}{c}\text { Geographic } \\
\text { Region }\end{array}$ \\
\hline R1 & 4th generation rancher & Female & White & U.S. Northwest \\
\hline R2 & 4th generation rancher & Male & White & U.S. Northwest \\
\hline N3 & NGO personnel & Male & White & U.S. Far West \\
\hline A4 & Academic/writer & Male & White & U.S. Southwest \\
\hline R6 & Academic/writer & Male & White & U.S. Southwest \\
\hline RN7 & $\begin{array}{c}\text { Rancher and NGO } \\
\text { personnel }\end{array}$ & Female & White/Latina & U.S. Great Plains \\
\hline RA8 & Rancher and Academic & Female & White & U.S. Northwest \\
\hline RN9 & $\begin{array}{c}\text { Rancher and NGO } \\
\text { personnel }\end{array}$ & Female & White & U.S. Great Plains \\
\hline N10 & NGO personnel & Female & White & U.S. Great Plains \\
\hline N11 & NGO personnel & Male & White/Latino & U.S. Far West \\
\hline R12 & 2nd generation rancher & Female & White & U.S. Northwest \\
\hline R13 & 2nd generation rancher & Male & White & U.S. Great Plains \\
\hline R14 & 1st generation rancher & Male & White & U.S. Far West \\
\hline R15 & 4th generation rancher & Male & White & U.S. Southeast \\
\hline
\end{tabular}

\section{Results: Literature Review}

\subsection{Defining Social Sustainability in Agriculture}

There is a considerable body of work examining the social dimensions of agriculture. Here we begin with a review of key sources that aim to explain social sustainability and its indicators in the context of agriculture. We then move to a broader discussion of relevant studies that use related terminology of community resilience, social justice, equity, health, and well-being rather than social sustainability. We chose these terms based on definitions of social sustainability discussed in the introduction.

One of the most comprehensive frameworks for assessing social sustainability in agricultural communities is presented by Janker, Mann, and Rist in the Journal of Rural Studies [28]. Combining Maslow's hierarchy of needs with a systems approach to understanding the various actors and interactions in the social agricultural system, this framework identifies the fulfillment of human physiological and security needs defined by human and labor rights as the minimum threshold for social sustainability in the agriculture sector. Beyond these basic requirements, social sustainability should also provide for additional human needs including belonging, esteem, and self-actualization for all actors involved in the agricultural system. What these needs are and how they can be met, the authors argue, depends on the local cultural contexts and thus universal metrics and indicators may be less useful than embedded, place-based studies of how social needs are met for actors in an agricultural system. 
Another particularly helpful article in identifying key indicators of social sustainability is Janker and Mann's analysis of eighty-seven sustainability assessment tools in agriculture [6]. Janker and Mann identified five reappearing themes in the eighty-seven sustainability assessment tools: human rights, work, life quality, impact on society, and context-embeddedness of social aspects. The work theme received the most attention, with over $50 \%$ of the tools assessing topics such as work hours, labor intensity, job training, and occupational health and safety. References to human rights, the next most common category, included the topics of gender equality and equity. Life quality included topics such as household food security, securing farm succession, life satisfaction, and livability. Societal impact incorporated such topics as land acquisition, stakeholder conflicts, and consumer education. Finally, although the tools rarely explicitly stated that social sustainability might vary between local contexts, a few were adaptable to specific contexts. The authors feel this place-specificity is important to analyses of social sustainability.

Other scholars have drawn attention to farm labor in both conventional and alternative agriculture as a critical aspect of social sustainability that is too often ignored in studies of sustainable agriculture that focus on farm owners. The low wages, occupational hazards, and vulnerability of undocumented migrant status experienced by many farmworkers are examples of the lack of social sustainability in agriculture today [29-33]. Others link social sustainability to risk mitigation and equitable social relations [33,34]. To further flesh out these later concepts that were not as frequently referenced within studies of "social sustainability," here we include an analysis of studies on agriculture and equity.

For example, a considerable body of work on gender and agriculture demonstrates that ensuring farms and ranches contribute to a socially vibrant and resilient society requires addressing the vulnerabilities produced in agricultural contexts through gendered norms and expectations. Gendered norms often delineate who receives farms in family succession, who makes farm decisions, and what type of resource access one might have $[35,36]$. Further, these norms can constrict both men and women into particular expressions of identity that may prevent them from meeting their needs for belonging and self-actualization $[37,38]$. A particularly illustrative example of the need to attend to gender in order to achieve social sustainability is Barbour and Guthman's study of pregnant farmworkers' exposure to pesticides in the strawberry industry in California [30]. They show that pregnant women farmworkers face socio-cultural barriers that make them less able to protect themselves and their unborn children from pesticide exposure compared to their male counterparts. Further, these women bore an additional emotional burden associated with the need to protect themselves and their children. We thus conclude that achieving social sustainability requires critical attention to how gender dynamics shape the ability of individuals to experience health, safety, and quality of life in agricultural communities.

Another body of scholarly work that brings important insights to a complete framework for evaluating social sustainability in agriculture is Black, Indigenous, and decolonial scholarship. These studies highlight the ways in which the agricultural system in the U.S. has been built on racial differentiation and the exploited land and labor of non-White people, beginning with the removal of Native Americans from their lands and plantation slavery from the 17th to mid-19th centuries [39-43]. Although these atrocities are in the past, their legacies have marked agriculture with a number of enduring racial inequities, so that Black, Indigenous, and other people of color (BIPOC) still often bear the largest health and safety risks in the industry and receive the least government support [43]. For example, in 1887 Native American farmers in the United States lost a significant amount of land when the Dawes Act regulated and subdivided tribal landholdings, giving many parcels to White settlers and leaving Native Americans with smaller communal holdings [44]. Today some federally funded conservation incentive programs for agriculturalists in the United States exclude Native Americans from qualifying because of these communal land tenure arrangements [45]. For Black farmers, discriminatory loan servicing and loan denial has led to foreclosure and the loss of their farms [46]. Finally, undocumented immigrants are frequently exposed to the worst labor abuses as they may be willing to work for low wages 
and in poor conditions because they fear deportation [47-50]. Montenegro de Wit [43] calls for the dismantling of these uneven systems of vulnerability through the cultivation of life-affirming institutions and relationships. This scholarship makes clear that greater racial equity in land ownership, working conditions, and livelihood security are critical to achieving socially sustainable agriculture. We now turn to work done specifically on social sustainability in the beef industry and particularly in cattle ranching.

\subsection{Social Sustainability in the Beef Industry}

A 2021 review article published in Sustainability systematically mapped literature on sustainability at the farm-level for beef and sheep production [51]. The study examined environmental, economic, and social sustainability where they included social equity, health equity, livelihood, labor rights, community development, community resilience, animal health, and animal welfare as aspects of social sustainability. The systematic mapping found thirteen out of twenty-two sustainability studies on cattle farms that included some analysis of the social pillar; nine of these were conducted in Europe and four in North America. The article demonstrates the relatively wide set of concerns necessary to a framework for evaluating social sustainability in cattle ranching as well as the limited number of studies done, particularly in the U.S. context.

One key source is Rivera-Huerta et al.'s study of twelve private cow-calf ranches in southeastern Mexico, three of which used monoculture, five of which used intensive silvopastoral systems, and four of which used native silvopastoral production systems. The study evaluates the twelve ranches for the social sustainability indicators of human rights, working conditions, and health and safety, and shows that there is little difference in the rankings between the three production systems and that all twelve ranches rank poorly on these indicators [52]. Another study evaluates the role of cattle ranching in achieving the tenth sustainable development goal to reduce inequality in Paraguay and Bolivia [53]. Findings indicate that cattle ranching exacerbates rather than reduces inequality except in cases where Indigenous communities' land rights and internal governance structures are respected and supported. A set of articles by Gosnell and colleagues demonstrates that in the U.S. and Australia beef farmers' quality of life and psychological well-being improved when they transitioned to more environmentally sustainable methods of production [54-57]. Together, these studies suggest that cattle ranching has not yet achieved social sustainability in most parts of the world.

A key challenge to social sustainability on U.S. ranches identified in the literature is shifting ranchland ownership dynamics, as wealthy absentee owners displace multigeneration ranch families in rural communities throughout the high amenity U.S. West and engage in different land and water management practices [58-61]. Loss of local knowledge, diminished opportunities for "neighboring" and shared labor, and divergent values around private property access and wildlife management (e.g., wolves, elk) can create conflict and impact community well-being and quality of life for established ranch owners/operators. In addition, nascent work on gender in ranching suggests that paying greater attention to women's experiences in ranch decision-making could play a pivotal role in improving material and cultural well-being by gaining a more complete understanding of the needs of ranching communities and families [62-64]. Further, some scholars have advocated for attending to animal welfare as part of social sustainability, given that animals' lives are part of the social system of the ranch and that the well-being of people and animals are linked [65]. Together, these works point to notions of well-being, equity, safety, and security on ranches as important elements of social sustainability.

Finally, a recently published article synthesizes sustainability indicators and metrics used by NGOs, agencies, and academics such as Audubon's Conservation Ranching Initiative, the Bureau of Land Management, the First Nations Development Institute, the Food and Agriculture Organization of the United Nations (FAO), and the U.S. Roundtable for Sustainable Beef (USRSB) [18]. The study evaluates twenty one assessments that collectively include 180 indicators and identifies twenty commonly-used "core" indicators of 
sustainability. Of those twenty, eight address socioeconomic well-being broadly, with three primarily social: rancher satisfaction with livelihood, rancher connection to community, and community health. We note that the first two relate to the ranch scale, while the latter relates to the community scale. There were no indicators identified that address social sustainability at the industry scale. The authors note that of the 21 approaches evaluated, only three included indicators related to equity, fair treatment, and employee rights for ranch workers. They portray this as a problematic gap in the way rangeland sustainability is conceptualized and measured and ask why these indicators are not prioritized by more entities within the beef industry. Related, there are efforts underway, though incomplete, to develop a "social" life-cycle assessment (LCA) in the beef industry. This approach is promising given the broad engagement of industry organizations with LCA as a means to assess environmental sustainability [66-68].

To conclude our review, we briefly describe the USRSB and its approach to sustainability assessment in the beef industry. In 2010, the Global Roundtable on Sustainable Beef formed, and five years later its U.S. counterpart formed with 94 members that included large players in the beef industry, such as the National Cattlemen's Beef Association, Cargill, National, Dreyfus, and Tyson, and support from a number of NGOs and land grant universities. In 2019, USRSB released a sustainability framework that drew heavily on the structure provided by Beef Quality Assurance [69]. The framework facilitates the assessment of sustainability in five sectors of the supply chain: cow-calf operations, the auction market, feedyard, packer and processor, and retail/food service. For each sector, an online assessment tool is provided for assessing one's operations according to six indicators (water resources, land resources, air and GHG emissions, efficiency and yield, animal health and well-being, and employee safety and well-being), and a guidance document is provided for improvement. For the cow-calf sector, this document is 48 pages long. Two pages each are given to advice on water resources and land resources, sixteen pages to air and greenhouse gas emissions, nine pages to efficiency and yield, twelve pages to animal health and well-being, and four pages to employee safety and well-being. We find this to be reflective of a larger pattern within the industry to give relatively limited attention to the social dimensions when compared to environmental and economic indicators. Nevertheless, efforts to coordinate and monitor amongst industry leadership are important and recognized characteristics that contribute to more sustainable supply chains.

Our review identified a number of indicators of social sustainability, including safe and healthy working conditions, good quality of life and personal sense of well-being, human rights including gender and racial equity, and strong community relations. We supplemented our review with interviews with fifteen key informants. The goal of these interviews was not to be statistically representative of all ranching experiences, but rather to identify current debates and concerns in the beef industry around the social dimensions of sustainability to allow us to build a more robust framework that can later be evaluated with a statistically representative sample.

\section{Results: Key Informant Interviews}

A qualitative analysis using thematic coding of fifteen interviews with thought leaders on social sustainability in the beef industry resulted in qualitative data that allow us to better flesh out the concept of social sustainability as it relates to the beef industry, particularly cow-calf operations, across industry, community, and individual scales. We begin with a broad analysis of terminology and indicators as described by our interviewees, then move into six emergent thematic areas: human health; rancher learning/adaptation; community relations/support; equity and inclusion; land tenure and succession; and industry structure. Finally, we conclude this section with our findings regarding barriers and pathways to social sustainability. 


\subsection{Terminology}

Interviewees consistently found the term "sustainability" to be insufficient in describing their goals for ranches. Instead, interviewees preferred words such as "regenerative", "resilient", and "adaptable", when applied to both social and ecological dimensions of ranching (R2, N4, RA8, R14). As one interviewee stated, "we have left [the word] sustainability a long time ago because to sustain is to keep it as it is, rather than to get to where it needs to be" (RN7). Another asked, "Why would I want to sustain a resource that is degraded?"(N11). A consistent dissatisfaction with the term sustainability among our research participants indicates that they believe sustaining what we have now is insufficient, and what is needed is recovery and improvement, in both ecological and social realms.

Key indicators of social sustainability described by our interviewees include physical, spiritual, and emotional health; community well-being; love; safety; nourishment; happiness; connection; relationships; stability; the capacity to care and have empathy; and a willingness to listen and work through conflict (R2, N3, A5). The following three quotes provide a sample of the breadth of definitions given by our interviewees:

But I think ultimately, people want to live in safe communities. They want people in their communities to be happy and healthy and well fed. And they want to live in community with other human beings that they feel connected to. (R6)

When I think of social sustainability, I'm usually thinking about the nature of how people communicate with each other about things that are really important. Then how do they respond in ways, either individually or collectively, that actually get to the heart of the unmet need, and how do they build the capacity to really make a difference over time? (R13)

So financial reserves are important. But also we need ... You guys will have to help me with the right words. Is it psychological? Is it personality reserves? ... we need emotional reserves so that when someone comes up and says, "We ought to get cattle off federal ranges," that [we] can ask some questions rather than snarl at them. If people say that cattle are bad for the environment, we ought to be able to ask questions rather than simply say, "No, they're not." So we have to have the capacity to absorb those blows to our emotions and come back as reasonable human beings. (R2)

One of our interviewees also described their understanding of a socially unsustainable ranch as one where the ranchers were mired in conflict, isolated, struggling economically, and "not having very much fun" (R13). The socially unsustainable rancher, the interviewee continued, feels that they are a victim of factors beyond their control, whether that be the government, climate change, or vegetarians; and so they are always angry, threatened, and complaining, and have difficulty adapting.

Many of the dimensions of social sustainability highlighted as important by our interviewees are not ones that can be easily measured using quantitative metrics and analytical tools. Rather, our interviewees indicated that several aspects of social sustainability are more subjective and qualitative, yet no less important than the more easily quantifiable dimensions of economic or ecological sustainability [N10]. This point speaks to aspects of social sustainability that require attention and effort on the part of the beef industry but may not be easily measured or supported by industry organizations. We explore those themes that were most prominent in our interviews here.

\subsection{Human Health}

One of the key themes that emerged from our interviews on the social sustainability of cattle ranching and the U.S. beef industry was that of human health and well-being. Indicators of human health and well-being are easily observable across multiple scales, including that of the individual ranch operation, the ranching community, and the national industry. Interviewees' comments under this theme emphasized that cattle ranching creates an opportunity for a healthy lifestyle and high quality of life as ranchers are active 
and outside frequently. One interviewee described the physical and emotional value of the lifestyle:

You get to be in open space, you get to be in nature, you get to be outside and you get to be in the weather. You get to experience the beauty of the land in a seasonal way that's unique... I just think the opportunity for quality of life is really high. (R1)

However, interviewees also described a number of risks to human health. In particular, a number of interviewees expressed concerns about high rates of depression and anxiety in the beef industry paired with a worry that most ranchers are unwilling to acknowledge or discuss these emotional health challenges. For example, one interviewee told a story of being at a conference attended primarily by ranchers where the speaker, an expert on mental health in agriculture, asked, "'How many of you have been depressed or know people who have been?' and almost every hand in the room went up" (A5). Another explained the pressure that can lead to mental health challenges in ranchers:

It's almost like our job in the world is to take care of the world, but to take care of the world, you've got to take care of yourself. If your business is relatively stable, you're more able, either as a ranch family or as an individual, to be able to respond to the needs of others. If you're really struggling and anxious and fretting about your business, you're going to have less energy capacity to help other people in your community. (R13)

Some interviewees described how stress and anxiety, along with a social culture of drinking, have led to alcoholism in some ranching communities that is a threat to rancher health. Another argued that it is not just emotional, but also physical health, that is at risk:

There's a toxic treatment of your body and that you should endure pain at any cost and never acknowledge when you're having physical discomfort. Even if that means you more profoundly injure yourself than if you just took [more] time. (R6)

Emotional and physical health are deeply tied to one another, and although ranching creates opportunities for a high quality of life and good health, there are currently a number of significant health concerns facing the ranching community. Further, although our interviews focused on cow-calf operations, it was mentioned that in feedlots and processing centers, many employees face health risks associated with their labor (N3). Finally, at an industry scale, the ways that beef is raised, finished, and processed impacts the quality of the meat, thus influencing consumer health (R15). Human health creates a crossscale linkage in considerations of social sustainability, as the method of meat production impacts the rancher, the rancher's community, the packaging/processing employees, and the consumer.

\subsection{Learning/Adaptation}

A second thematic category to emerge from our interviews is the importance of learning and adaptability to a socially sustainable beef industry. Interviewees highlighted learning across multiple scales; for example, they mentioned learning to use new technologies and big data to adjust ranching practices according to emerging needs (A4). They also highlighted the importance of multigenerational learning between members of the family. Elders must pass knowledge to younger family members to maintain that knowledge, but elders must also be open to new knowledge obtained by younger generations off the ranch and brought back (R1, R12).

Oftentimes a ranch family is a multi-generational thing ... so you want all of the generations engaged in hearing the new learning because they make decisions based on that. [This] is also part of social sustainability, for the ranchers to have access to relevant educational opportunities in their communities or that they can go to [and where] they feel welcome. (R1)

The interviewee went on to describe the importance of a social network in facilitating that learning: 
Sharing knowledge. Sharing new ideas. And ... I think it's interesting to think where do those things happen in the ranching community? To me, they happen at the brandings, at the ball games, at the memorials, at church, at [organization] annual meetings. Where else does that happen? So that network is really important. (R1)

In order to facilitate this continual learning and adaptation, interviewees highlighted the need for ranchers to remain open-minded. More than that, interviewees argued that it was critical that ranchers listen with respect and openness to criticism. To do so, one interviewee argued that ranchers need to build up a deep emotional reserve, or a sense of personal value and an emotional support system, so that they can acknowledge problems and begin working to rectify them:

I have a friend that lives in [western town], and he sent me an email. He said, "You know what? Every time I read about the [beef industry] and their [ideas about] climate change, all they say is, 'We're good for the planet... ' and they always sound defensive." And he said, "I would love it if [ranchers] just once would say, 'You know what? We might be part of the problem, but it's a problem that all of us share, and here's what we're doing to tackle it ... '" And I don't know how to respond to that except that we ought to have those emotional reserves that we [can] say, "Well, you know we might be. Let's look at this together. Are those numbers right? Guys, maybe here's something we ought to study further," rather than just going off to our corners and start pounding each other. (R2)

Like this rancher, many interviewees emphasized the need to remain open and undefensive, seek out and share new knowledge, and build emotional resilience so they are prepared for productive dialogue (R1, R2, N4, A5, R6, R12). Learning and adaptability were not indicators of social sustainability that emerged from the literature review; rather, they emerged inductively from the interview data where many interviewees emphasized the importance of these traits to rancher well-being, sustainable and resilient ranches, and a socially-vibrant beef industry.

\subsection{Community Relations}

Consistent with the scholarly literature we reviewed, our interviews revealed that ranchers' relationships with others comprise a key aspect of social sustainability. There was a common sentiment that ranchers must cultivate their social networks strategically. One interviewee referred to this set of relationships as a "spider's web" that includes other ranchers, community members, stakeholders, public land and wildlife managers, urban people, consumers, Indigenous peoples, and any others with a stake or interest in how public and private rangelands are managed and how beef cattle are raised (N11).

When I see a rancher that I would call sustainable, it's that person who is embedded in the community, the school, church, whatever. They're networked with conservation organizations, the Farm Bureau, HMR Service, NRCS, you name it. They can establish their spider web of support. Those are the ones that are successful. (N11)

So all of the nodes [in the network] need to become a lot closer. And the rancher, too, needs to become closer to the scientist, to the market, and explain, teach, share ... share the pain points, share the fears, share the challenges. (RN7)

Interviewees noted that a healthy social network will support a rancher when challenges arise, making them less vulnerable to shocks, stressors, and unexpected crises. Further, a cultivated network can improve consumer trust and reduce conflict between stakeholders.

How willing are you as a ranching community to work with nontraditional partners that are actually interested in your well-being, like The Nature Conservancy or Audubon or World Wildlife Fund? Or working with agencies in a positive way that creates opportunities for you and maybe reduces potential regulations by entering into extended voluntary agreements. Now we're seeing groups, and you can get at the heart of social sustainability, you're seeing these ranchers in [western state] organizing around these 
themes and working with these kind of partners to tell the story of what we do, how we do it, and why can we be a trusted partner taking care of public lands. (R13)

In addition to good relations with stakeholders with interests in land, water, and wildlife, there is a felt need for mutual understanding, respect, and empathy between ranchers and beef consumers, many of whom are urban people.

As long as I can remember, we in agriculture have talked about the importance of urban people having a better understanding of agriculture. But we never put the shoe on the other foot and say, 'Rural people ought to have a better understanding of what's going on in [western city].' (R2)

I see a lot of farmers complaining that they feel misunderstood and that they're victimized and that urban populations don't understand their concerns. And I see very little reciprocated compassion for the concerns of urban people and people living in cities, who are the people that we feed and ultimately serve. The reason why we exist is to create sustenance for these people. And so I feel like that's a conversation that should cut both ways ... What are you doing to understand what other people are experiencing right now and what concerns they care about? (R6)

In other words, socially sustainable ranchers make a conscious connection with consumers and strive for awareness of their evolving concerns and needs. Conversely, healthy urban-rural relationships seek to reduce the disconnect between consumers and the reality of where their food comes from. Consumers should cultivate an appreciation for the challenges ranchers face in their roles as stewards of natural capital upon which urban people depend. Ignorance and misunderstanding between ranchers, consumers, and other stakeholders is a key threat to the social sustainability of the beef industry.

In some cases, socially sustainable community relations demand accountability and rectification, for example where the community includes Indigenous peoples whose lands ranchers now own and manage. A growing number of ranchers are coming to terms with the history of their land, and, for some, this is leading to a desire to engage in rectification.

And why was that land even available to be purchased [by my grandfather] in the first place? Because the [name of local tribe] Indians were displaced through this incredibly brutal war... And so, there was this whole history that now I'm just starting to really learn more about, that's the real truth behind the colonization of this place. And from there, that begs the question, what is regenerative agriculture? And what are we regenerating? And that's where I'm sitting right now. (R6)

Community relations are determined in part at the ranch scale, i.e., how the rancher interacts with others; but they are also inextricably related to the legacy of settler colonialism and the structure of the U.S. beef industry, which, according to some of our interviewees, exacerbates the disconnect between producers and consumers. Social sustainability demands that ranchers work to overcome the various disconnects described here.

\subsection{Equity and Inclusion}

Our interviewees frequently brought up themes of equity and inclusion, indicating a growing belief that social sustainability in ranching cannot be achieved without rectifying inequities that exist within the beef industry. Interviewees identified three aspects of equity and inclusion that need to be addressed. First, diverse representation in decision-making is needed and does not currently exist in most ranches and beef organizations. Second, structural inequities in land and resource access resulting from unjust historical policies and practices need to be rectified. Third, rural cultural norms and behaviors should be reworked to be more inclusive of non-majority identities such as women, LGBTQ+ people, and people of color (R1, R2, R6, RN7).

The first aspect of equity and inclusion highlighted by interviewees was the need for more diverse representation in decision-making in order for ranching to adapt to current challenges and sustain itself into the future. However, diverse representation 
alone is insufficient without a simultaneous shift in power structures so that previously marginalized voices have power and sway (R6). To achieve this, interviewees argued that we must address those institutional arrangements and barriers to entry that have frequently excluded people of color, women, and LGBTQ+ people from cattle ranching (R1, RN7). This reflects the second aspect of equity and inclusion that interviewees highlighted: structural inequities.

Interviewees provided examples of the ways that their White families had succeeded in their industry because they had access to resources unavailable to people of color (R1, RA8). For example, one interviewee explained, "We got ahead in ranching because my father could get the GI bill because he was a GI and White men got the GI bill" (R1). African-American veterans had a much more difficult time obtaining benefits from the GI bill [70]. If those who could not get capital seventy years ago had difficulty getting into ranching, the barriers to entry seem even higher today. One interviewee explained the barriers to entry for people of color in this way:

So, when someone says to me, "Why are we not seeing people of color [in ranching]?" Well, holy hell, if [White] people can't even get an FSA loan, I have very little faith that a person of color or a person who has not had a lifetime of [advantages] in an industry is going to have access to this money. And, yes, agriculture is so heavy on necessary capital to get started and the margins are so low, it is an extreme barrier for any person who is not independently wealthy to somehow get into agriculture. (RN9)

Not only are there significant barriers of entry for low-income people and people of color to become ranch owners and decision-makers, but those who do surmount those barriers and bring in new perspectives bear an immense emotional burden:

Unfortunately, anyone who is in a position [where] they are not the dominant decision maker and they are trying to shift and make change, they are taking the weight and the burden of society and tradition and culture, [which is] continuously signaling to them, in soft and firm ways, 'You need to get back to the spot that was designed for you. We're all much more comfortable when you're in your place and we're in our place.' And that can be an exhausting experience ... . When I say dominant culture in ranching, I'm saying White males is the dominant decision-making culture. (RN9)

This interviewee went on to explain that shifting the dominant culture is difficult (the third aspect of equity and inclusion identified by interviewees). It takes work to create a space that welcomes difference. They suggested that this is because it is more efficient not to have differences, but instead to have similar mindsets. Efficiency has long been a driving motivator for the beef industry.

Although women are active on ranches and are often influential in certain aspects of the ranching industry, women also frequently cope with exclusion and inequity in ranching. Interviewees consistently pointed to the pivotal roles of women on ranches, including everything from cooking to roping (R1, R2). In particular, several interviewees highlighted that women have played notable roles in the ecological conservation aspects of ranching and conflict resolution between ranchers and others (RN9, N11). Some interviewees felt that because women do indeed often hold pivotal positions on ranches, that perhaps gender inequity is a thing of the past at the ranch scale; however, they still saw it in play at the beef industry scale (R1). Other interviewees gave examples of how gender discrimination continues at all scales of the industry. For example, women are exposed to more sexual harassment than their male counterparts (R6). Further, women often face pressure from their families not to go into ranching and/or are given very limited decision-making roles (R6, RN9). Several female interviewees explained how their brothers had been given the ranch despite not wanting it, while they were told that the ranch was their brother's opportunity, not theirs (R6, RA8). One interviewee shared the experience of returning to take over the ranch from her father and how she was constantly ignored by his friends and the workers she encountered in her daily duties: 
We would go to buy hay and load the hay up... and my dad would chat with whoever the old dude we were buying hay from was. I would be sitting in the truck or standing there and there would be no acknowledgment that I existed. Nor did my dad pick up on [the idea] that maybe that was weird, but I remember just feeling like, 'Whoa, am I even here?' (R6)

Importantly, interviewees pointed out that women sometimes reinforce the patriarchal structure of the ranch, as they are socialized from a young age to see it as normal:

Women who grew up in it ... they just say all these positive things about their dad, and talk about their dad all the time, and I always say, "Where was your mom in these stories?" I don't know. Cooking, or whatever, like, she likes being in the kitchen... Like, they're not even processing the system that their mother is in and the generation that she was in. And this bizarre affectation towards the patriarch... and I always wonder what she's assuming if she marries a rancher, what that's going to be like for her. Because very likely her husband will have grown up in the same tradition she did, and his assumption will be that she'll be in the kitchen and taking care of the kids. And that is completely fine, there's nothing wrong with that, but I can guarantee you, [many women I know], they're not telling me, "That's what I long to do. That's the only thing I long to do." (RN9)

Interviews made clear that the beef industry has a long way to go in achieving equitable access to land, resources, healthy working conditions, decision-making, and respect for women, LGBTQ+ people, people of color, and the poor on cattle ranching operations, in ranching communities, and in the broader industry. For our interviewees, achieving greater equity and inclusion is critical to building a socially sustainable beef industry.

\subsection{Land Ownership, Tenure, and Succession}

Another recurring theme had to do with the role that land ownership, land tenure, and succession play in social sustainability. Interviewees highlighted the challenge of buying land to begin ranching without pre-existing wealth; and the ways in which historic land policies and cultural values have largely limited land succession opportunities to mostly White men already in ranching families. Many families are faced with succession challenges and conflict around how the ranch will continue when the patriarch passes.

I've met a lot of young women that really are excited and passionate about using livestock to manage landscapes. And I just know that there is no financially viable path for them to get started now in the context that they're operating in. Compared to when my great grandparents were leasing land and then my grandfather was able to buy it. But he paid $\$ 2000$ for the original piece of land that he bought here. And he got a loan from a relative who was a very successful wheat farmer. So, that is not a path to land ownership that was open to a lot of people. (R6)

Interviewees noted that in many ranching communities, the next generation is opting for opportunities off the ranch, for a variety of reasons (RN7). To sustain the family ranch tradition, young people need to be welcomed back, made to feel heard, and see their new ideas incorporated (R1, R12). This relates to the points discussed under Learning/Adaptation.

I think what's more important is getting a welcome mat out in rural areas for young people, whether they grew up in those areas or are from urban areas, that we need to create better jobs and ways of making a living for young people in rural areas. (R2)

I know that we need more people that want to learn how to do this stuff because the people that are doing it now are getting freaking old. And so we need to be recruiting young people. (R6)

Some suggested that ranchers should consider other people to hand the ranch off to besides the oldest son. This could be a daughter, an apprentice, or an employee, for example (R6). 
A complicating factor for the future of ranch land ownership is the rapid rise in agricultural land values over the past few decades. This has made it more difficult for ranchers to own land and pass it on to their children. Ranch land in many places is worth more than livestock production value. These trends are resulting in development and land conversion on the one hand and ownership changes involving absentee and/or amenity buyers with different land management priorities on the other.

Are we creating a system in which the next generation or generations are able to continue ranching? What are the barriers to that? In California, we lose 20,000 acres of rangelands [to development] every year. (N11)

We've seen land get more valuable. But it's not valuable for its natural resources or what its natural resources can produce. It's valuable for its solitude, its beauty, its hunting, things that we normally do not put an economic value on. These are what, ironically, are driving up the value of these ranches. So you asked, is that a good thing or a bad thing? And it's neither. It's just a thing. And so we have to adapt to it. (R2)

There was already a lot of absentee buyers buying up the American West, and then COVID happened, and we have just seen an explosion in the state of Montana of absentee buyers who know nothing about land stewardship and land care... How can we make working lands viable and keep people in these rural communities? (RN9)

These newcomers are displacing family ranchers and, in some cases, replacing cattle production with an emphasis on fish and wildlife management, leading to a perceived decline in functional working landscapes throughout the West. Several interviewees commented that ranchers are having to adapt to this new reality and noted that there are pros and cons to this ownership transition.

To prevent large-scale land conversion, ranchers need to cultivate strategic partnerships with nonprofits, land trusts, and philanthropic investors interested in preserving working landscapes. This relates to the theme of community relations, discussed above.

Their dependence on other ranchers depends on the rural feel of the community and this is also crucial because as ranchers sell their land and the neighbors are not there to help them, their feed store moves further away, the vet moves further away. Every time we lose a rancher, the rest of the ranchers also take a hit because again that infrastructure, that network, social network keeps getting eroded and eroded. That connection with just their home, fellow ranchers is really important. (N11)

To deal with the growth in absentee and amenity ownership, ranchers need to learn how to work with absentee landowners, many of whom are wealthy and have different values and priorities for their land. When the owner is not the operator, there can be a disconnect (N11). However, in some cases, absentee owners are interested in investing in the local community (RN9, R2). Thus, absentee owners were not inherently considered a negative by interviewees, but our interviews did show the importance of productive relationships between on-the-ground ranch managers and absentee owners to ensure good land stewardship and community contributions (R2, N11).

One interviewee noted that some of the best opportunities for future ranchers may be as managers for wealthy absentee owners. This may create opportunities for those who cannot afford to buy land to enter ranching, but it also requires a different skill set that includes communication skills, presenting a vision to an owner, and building a business plan (RN9). Further, while ranchers do not need to own the land on which they raise cattle, security of tenure can be important to healthy communities because people who have a sense of security may make more long-term decisions.

So land ownership in itself is not a prerequisite for a healthy community. However, land ownership might give you a sense of tenure on the land and more effective long-term decision-making. So I think you can throw that out as well. But is there something valuable in family-owned, family-operated ranches continuing in the West? I think there is, but it isn't the ruination of the West that land values are up so high. (R2) 
Issues related to land ownership and succession are relevant to social sustainability at the operator scale in terms of family legacy and family dynamics; at the community scale because of the ways in which owner operators contribute to rural community vitality; and at the industry scale, as family ranchers producing beef are increasingly at risk of being replaced by absentee owners and large corporations.

\subsection{Industry Structure}

Interviewees had a lot to say about the tensions between the beef industry, social sustainability, and, especially, community resilience. A common observation was that the centralized industry structure with its emphasis on efficiency has had a negative impact on rural communities, and that what is good for the industry is not necessarily good for the community, the individual rancher, or the animals. One rancher observed that rural communities throughout the U.S. that were thriving in the 1950s and 1960s have become "ghost towns" (R15) due to the loss of local infrastructure and associated jobs.

So, the economic impact on the local community is a function of the centralization. Instead of having small abattoirs scattered throughout the countryside that were a local economic driver, it was centralized into huge slaughter plants, fabrication plants that would slaughter hundreds of head per hour. And when doing that, they made the packing branch incredibly efficient. They lowered the cost per unit of slaughter dramatically. And that's a good thing for the packer. It also rendered the small towns economically irrelevant. The local community was not needed anymore. (R15)

And what factory farming did is remove it from that social context, and just take an engineering perspective, ask how you can extract the most from the animal. And it doesn't matter if you end up with something that's socially abhorrent, do it anyway. That was the spirit of early factory farming. And this is why factory farming has all these welfare problems that your traditional animal husbandry doesn't, because there have always been moments of trade-off between what's good for the animal and what's good for the economy. (N3)

This last quote draws the connection between animal and human welfare, suggesting that both are too often compromised in the current beef industry structure. The quote also stresses the importance of the social context of the rural community, as does this one:

Agriculture, and especially since industrial agriculture took over, and the whole food system, as it is today, has prioritized volumes and efficiencies and has eroded ecological and social richness and capital. So we have lost a lot of our traditions, a lot of our culture, a lot of our indigenous knowledge... on how to do things. And with that goes so much social, cultural, traditional, wisdom and richness. (RN7)

This quote suggests that the maintenance of culture, knowledge, and tradition may be an indicator of social sustainability, a theme that emerged briefly in our literature review [71]. For the above interviewee, the beef industry's current structure makes these social sustainability indicators difficult if not impossible to achieve. Similarly, the next quote, from an interviewee reflecting on a recent drive across the U.S. Great Plains and South, connects the loss of strong social structures and well-being to the current industry structure:

But I'll tell you, we were in a food desert for one thing [as we drove through cattle country]. The grocery stores, the communities ... I just can't even get over it. Like how absolutely degenerated, unsustainable the ranch country is and so the only places that you see any kind of vibrancy, maybe are places that have been gentrified, but the gentrified places, you can't buy ranches there. Anyway, it's incredibly sad. So I do not see that the beef industry is contributing anything that I can see to social, ecological, and economical sustainability. It is contributing to huge industrialized agriculture. (RA8)

Interviewees suggested that to achieve social sustainability at the ranch, community, and industry scale, it would be important to decentralize the industry structure to build lo- 
cal economies and rekindle traditional cultural practices associated with animal husbandry and slaughter (N4, R14).

There's a lot of tradition around just livestock, the cow and how it's raised, how it's tended to, how it's killed, how it is prepared and consumed. There's tradition and there's community in all of that. How do we rekindle that? And for that, I think we'll need all of us, the whole, what I call value network or value web, not supply chain, because it's not linear and it's not just the supplies. (RN7)

According to another interviewee, this linear system focused on efficiency does not provide the breadth of rural jobs and community relations that would mark a socially sustainable ranching community (R15).

One rancher suggested that public opinion has swayed so strongly against feedlots that the industry should consider moving away from them in order to maintain and repair consumer trust (RN9). This interviewee asked how beef and corn might be decoupled so that new approaches to the country's farmland could become an option. If we no longer needed to plant corn in the Midwest for feedlots, how might we use that land and what new forms of socially and ecologically resilient communities might emerge (RN9)? However, they recognized that ranchers' choices to work within the current industry structure are profoundly shaped by government policy and economic need:

The major problem I see [to] changing folk's paradigms, is the fact that current government policy is set up to keep beef and corn coupled. The subsidy system has farmers planting things that might make zero sense from a soil health/regenerative standpoint, but they know they can get paid for what they are currently planting... [but] when we are asking people to change, we must be very, very aware that we are talking about people's livelihoods and their ability to keep the family farm/ranch together. If it is currently working for them, and we are asking them to get more creative, there must be a tandem movement occurring to create policy which is in support of such change. (RN9)

Interviewees emphasized the system's vulnerability, and some pointed to breakdowns during the recent COVID-19 pandemic as evidence of this vulnerability (R1, RA8, RN9). As synthesized here, interviewees felt that the structure of the industry needed to shift away from linear supply chains and efficient production towards the cultivation of strong local economies and extensive social networks that would provide rural communities with more and better livelihoods; renewed culture and knowledge sharing; and vibrant social lives.

\subsection{Barriers and Pathways to Social Sustainability}

Our interviewees also provided insights into the key barriers and pathways to social sustainability. At the individual rancher scale, interviewees identified risk aversion, an unwillingness to listen and learn, and poor planning for succession as major barriers to achieving social sustainability (R13, R15). They identified neighborly support and community building as important pathways to achieving social sustainability at the ranch scale (R2, N11). Further, they said good succession planning and retaining knowledge through generations was also critical (R2).

At the community scale, interviewees identified a lack of diverse perspectives, land values that prevented working landscapes from being economically viable, and a lack of access to land and capital as major barriers to achieving social sustainability (R1, R2, R6). As one interviewee stated:

I don't know, I just feel like land is so incredibly expensive and inaccessible to any person trying to start out, and certainly if you're not a person that has at least some seed of startup money, I do not see how it's viable to start at all a functioning livestock operation. Most of those programs that incentivize require years of business history, financials, and so you have to be able to at least [do] something on a small scale and that is not always... that can be really time consuming and not financially rewarding. So I think we're already putting a big barrier before people can access a lot of the startup financing that's available. Yeah, and if you're poor, you have bigger problems. (R6) 
Important pathways they identified at this scale included community co-ops such as Country Natural Beef, developing relationships and trust between producers and consumers by visiting retail stores or inviting consumers to the ranch, ensuring there are good schools in the community, creating opportunities for dialogue and diverse ideas, and building organizations that allow members to participate in the betterment of their community (R2, RN7, N11).

Finally, at the industry scale, interviewees identified the size and structure of the industry as a barrier to nimbleness, responsiveness, and adaptability, making change difficult. They considered the inability to decouple beef and corn, a monopolized industry, a focus on efficiency and volume, and lack of government support for small-scale, grass-fed, and non-conventional methods of ranching to be major barriers (RN7, RA8, RN9). One interviewee explained that support agencies have had their budgets cut and their human resources stretched thinner:

At the same time that we keep raising the bar, particularly for the ranchers [to produce beef that is environmentally friendly, cheap, available year around, etc.], we have dismantled the network of support that they used to have through the Natural Resources Conservation Service, conservation districts, cooperative extensions, and Farm Service Agency. All those budget cuts and allocating the money to different things, different programs... We ask more of them, but at the same time, we took away the support that they had. Let's bring that support back. That'd be a start ... [but incentivize] good stewardship, good practices and stop subsidizing bad practices, because that's part of the narrative that the urban folks have is that you don't know if farmers are being subsidized and they're just polluting the water and the air and the soil and all that. (N11)

Interviewees had many ideas for structural changes at the industry level that they felt would create pathways towards more social sustainability in the beef industry. For example, several interviewees argued that a more decentralized beef industry would facilitate a production process with better opportunities and quality of life for employees and better relationships between producers and consumers. One interviewee suggested that we need to change the culture around beef production and consumption. Rather than quantity and price being driving factors, they suggested that beef could be marketed like wine, known for its terroir and its careful cultivation with deep knowledge of the land on which it was grown and the people who harvested it. They stated, "Another one of the big obstacles is the actual supply chain design, that is designed for volumes and consistency and not differentiation and richness and uniqueness" (RN7). There was consistent concern with the ability of the feedlot system to deliver a truly environmentally and socially sustainable product, and interviewees urged shifting away from feedlots and into seasonal beef production methods on ranches. This would require consumer education so that they accepted seasonally available meat and meat that was more expensive than feedlot beef.

There's a lot of investment that needs to happen in the right things. Shortening the supply chain into a relation of value networking, investing by all nodes, education at all levels, and tons of storytelling work, a way to get these out so public opinion can shift, and therefore policy will follow. (RN7)

Our interviews indicate that the centralization and focus on efficiency of the current industry structure are barriers to social sustainability across all scales, but education, policy shifts, and storytelling may be pathways to shift the industry structure.

\section{Discussion}

In this section, we propose a framework for assessing the social sustainability of cattle ranching that includes results from the literature review as well as those that emerged inductively from the interviews. We organize our framework indicators by thematic area and across three scales of analysis: the ranch, community, and industry. We intend this framework to serve as a starting point for a deeper engagement with social sustainability 
issues in the pre-harvest portion of the beef industry. In this section we also discuss crossscale linkages and implications for enhancing social sustainability in the beef industry.

Our literature review provided insight into how social sustainability is currently perceived and addressed as part of broader sustainability frameworks in the beef industry. In assessment tools used by various industry stakeholders, rancher satisfaction with livelihood, rancher connection to community, and community health are common indicators of the social pillar of sustainability [18]. Many evaluation tools, including those used by the USRSB, include animal welfare and employee safety as indicators of social sustainability. Other indicators referenced in the academic literature include human and labor rights, equity, and psychological well-being. Below we highlight five findings that emerge when comparing the themes identified in the literature review with those that emerged in our interviews.

First, we note that while working conditions and employee safety were key themes of social sustainability in the literature, working conditions were only minimally discussed by our interviewees. Although we asked about working conditions and labor on cow-calf operations, few of our interviewees spent time discussing this topic. We posit that the lack of discussion on working conditions at the pre-harvest ranch level when compared to the post-harvest sectors may indicate that hired help on ranches is an understudied topic in rangeland science (see also [26]). We posit that hired, seasonal laborers, and even family members in the ranching sector are still profoundly impacted by working conditions and that this aspect of social sustainability on cow-calf operations requires more attention.

Second, while both the interviewees and academic literature discussed equity and inclusion as critical aspects of social sustainability, this topic is elided in social sustainability frameworks currently used by beef industry organizations. We observed nothing related to equity and inclusion in the USRSB framework, and Ahlering et al. found that only three of the twenty-one approaches they analyzed included attention to equity, fair treatment, and employee rights $[18,68]$. Our interviewees gave countless examples of why equity and inclusion in the beef industry are necessary to achieve the conditions of social sustainability. For example, while all ranchers frequently experience insecurity due to consumer skepticism of the beef industry, rising land costs, and younger generations not returning to the ranch, women ranchers, ranchers of color, and undocumented immigrants working on ranches have long lacked security within the beef industry as they struggle for succession rights, decision-making roles, and recognition of their contributions. Interviewees suggested that these experiences not only affect their sense of security, but also their ability to meet esteem and self-actualization needs, needs identified as necessary for social sustainability by Janker, Mann, and Rist [28]. Further, interviewees suggested that more diverse social representation in the beef industry would create a more resilient system and a healthier community, just as ecological diversity improves the quality of the environmental system. Thus, we conclude that equity, and inclusion must be high priorities for achieving social sustainability.

Third, and relatedly, our findings show that achieving equity and inclusion requires a deep reckoning with discriminatory histories and systems, rather than simply a metric for having more women or people of color in ranching. The literature on food justice [40-43] provides a necessary addition to that on social sustainability in agriculture by showing the changes that need to happen to create a system where people of diverse backgrounds can engage in healthy, fulfilling, and secure food production livelihoods and can be guaranteed respect and opportunity.

Fourth, our findings indicate that animal welfare is important to a socially sustainable and just beef industry, yet, simultaneously, ranches and organizations must be careful not to elevate animal welfare above human social needs. For example, consumer concern for animal welfare has led many ranchers to use animal welfare certification tools to reassure consumers that they employ animal-friendly methods. This is valuable, yet we observe that there are few certification efforts to ensure equitable and fair treatment of laborers in the industry. The danger here is that animal welfare could become a sort 
of "stand-in" for other social sustainability concerns such as the inequitable and poor treatment of underrepresented groups in the beef industry. Both the scholarly literature and our interviewees argued that human and animal welfare are connected and urged industry sustainability frameworks to better attend to human welfare alongside animal welfare $[48,65]$.

Fifth and finally, our interviewees consistently emphasized strong community relations at multiple scales (for example, between neighbors, producers and consumers, and urban and rural communities), dialogue across difference, and ongoing social learning by all members of the beef industry as key indicators of social sustainability. The prevalence of these topics in our interviews stood out given their absence in the scholarly literature, though we did find brief mention of governance and rancher connection to community $[18,52])$. This discrepancy suggests that these dimensions of social sustainability have received inadequate attention and require deeper attention in sustainability frameworks and evaluation tools.

Drawing on these findings, we have developed a set of indicators of social sustainability at the ranch, community, and industry scales for the pre-harvest sector of the beef industry (see Table 2). Each of the indicators is linked to those at other scales so that achieving social sustainability at the ranch scale is dependent upon achieving social sustainability at communal and industry scales and vice versa.

Table 2. Indicators of social sustainability in the pre-harvest sector of the beef industry at three scales.

\begin{tabular}{|c|c|c|c|}
\hline & Ranch Scale & Community Scale & Industry Scale \\
\hline Human Health & $\begin{array}{l}\text { Ranchers have good physical } \\
\text { health }\end{array}$ & $\begin{array}{l}\text { Community has physical } \\
\text { and mental health services } \\
\text { There is awareness, } \\
\text { acceptance, and support for } \\
\text { health challenges }\end{array}$ & $\begin{array}{l}\text { The beef provided to } \\
\text { consumers is high quality } \\
\text { Working conditions } \\
\text { throughout the industry } \\
\text { are healthy }\end{array}$ \\
\hline $\begin{array}{l}\text { Learning } \\
\text { and Adaptation }\end{array}$ & $\begin{array}{l}\text { Ranchers utilize new ideas } \\
\text { and technology }\end{array}$ & $\begin{array}{l}\text { Community members } \\
\text { dialogue across difference } \\
\text { Opportunities exist for } \\
\text { social learning }\end{array}$ & $\begin{array}{l}\text { Industry organizations } \\
\text { facilitate learning } \\
\text { opportunities }\end{array}$ \\
\hline $\begin{array}{l}\text { Community } \\
\text { Relations }\end{array}$ & $\begin{array}{l}\text { Ranchers cultivate relationships } \\
\text { with stakeholders and consumers }\end{array}$ & $\begin{array}{c}\text { Forums exist for } \\
\text { community dialogue } \\
\text { Community members } \\
\text { participate in collaborative } \\
\text { problem-solving }\end{array}$ & $\begin{array}{c}\text { Industry organizations } \\
\text { solicit and respond to } \\
\text { feedback from ranchers and } \\
\text { consumers }\end{array}$ \\
\hline Equity and Inclusion & $\begin{array}{l}\text { People from diverse backgrounds } \\
\text { have equitable roles in } \\
\text { decision-making } \\
\text { All people on the ranch feel safe } \\
\text { and respected }\end{array}$ & $\begin{array}{l}\text { Diverse constituents feel a } \\
\text { sense of belonging in } \\
\text { the community } \\
\text { Efforts are made to recruit, } \\
\text { train, and support people } \\
\text { from underrepresented } \\
\text { groups to participate } \\
\text { in ranching }\end{array}$ & $\begin{array}{c}\text { Industry governance } \\
\text { characterized by } \\
\text { diverse leadership } \\
\text { Inequitable impacts of the } \\
\text { industry are addressed, e.g., } \\
\text { there are opportunities for } \\
\text { BIPOC to own/control } \\
\text { means of production }\end{array}$ \\
\hline $\begin{array}{l}\text { Land Ownership, } \\
\text { Tenure, Succession }\end{array}$ & $\begin{array}{l}\text { Next generations return to the } \\
\text { ranch } \\
\text { Ranches have succession plans }\end{array}$ & $\begin{array}{l}\text { Owners are invested in } \\
\text { the community } \\
\text { Invested community } \\
\text { members have the } \\
\text { opportunity to own }\end{array}$ & $\begin{array}{l}\text { Land market and beef } \\
\text { prices allow for working } \\
\text { landscapes to be profitable }\end{array}$ \\
\hline Industry Structure & Ranches provide secure livelihoods & $\begin{array}{l}\text { Communities are vibrant } \\
\text { and livable } \\
\text { Good paying rural jobs in } \\
\text { beef exist }\end{array}$ & $\begin{array}{l}\text { Organizations are held } \\
\text { accountable for social } \\
\text { sustainability indicators } \\
\text { Monitoring programs are } \\
\text { in place }\end{array}$ \\
\hline
\end{tabular}


Achieving a socially sustainable, regenerative, resilient, and adaptable beef industry will require that we attend to indicators as they cross these themes and scales. For example, an indicator of a socially sustainable ranch at the ranch scale is that future generations return to the ranch, which is dependent upon a land market that allows for intact working landscapes, an industry scale indicator. There are also linkages across themes. For example, communities dialoguing across difference, an indicator of rancher adaptation and learning, is necessary for collaborative problem-solving, an indicator of socially sustainable community relations. A final significant consideration is that our summary of barriers and pathways to social sustainability, as identified by interviewees, shows that indicators of social sustainability at one scale and in one theme may often serve as a pathway towards social sustainability at another scale and in another theme.

\section{Conclusions}

In this paper, we have explored the concept of social sustainability in general and as it relates to the agricultural sector and the U.S. beef industry more specifically. We identified key themes in the scholarly literature and used them to develop an interview guide for fifteen conversations with thought leaders on the topic of social sustainability in the beef industry. While some of what we heard reflected what we had learned from the literature, a number of surprising new themes emerged; and our qualitative approach gave interviewees the opportunity to contemplate strengths and weaknesses of the current system, share stories and experiences, and visualize alternative futures. Based on our experiences and findings, we suggest that future efforts to evaluate social sustainability would benefit from an approach that creates space for qualitative insights, rather than focusing solely on indicators that can be measured quantitatively.

Another core finding has to do with the term social sustainability itself, which was at best opaque to many of our interviewees and, more often than not, unsatisfying and less desirable than terms like resilient and regenerative. The latter terms were more compatible with interviewees' efforts to imagine a positive future, while many agreed that sustainability felt like a low bar. When the current situation is less than desirable, sustaining it does not make sense.

Key indicators of social sustainability identified in this research can be organized under the themes of human health; learning/adaptation; community relations; equity and inclusion; land ownership, tenure, and succession; and industry structure. Indicators were examined across the ranch, community, and industry scale and cross-scale linkages were identified. A final important point emerging from this project is that systemic changes are needed in order for the beef industry to better balance the three pillars of sustainability. There is a need for future research that builds on the nascent ideas presented here and that explores alternative future scenarios for the U.S. beef industry, including those that might emerge from a value system not built around efficiency and volume.

Author Contributions: Conceptualization, H.G., K.E. and E.H.; literature review, H.G., K.E. and E.H.; interviews, H.G., K.E. and E.H.; data analysis, H.G., K.E. and E.H.; writing-original draft preparation, H.G., K.E. and E.H.; writing-review and editing, H.G., K.E. and E.H.; project administration and supervision, H.G.; funding acquisition, H.G. All authors have read and agreed to the published version of the manuscript.

Funding: This research was funded by the Beef Checkoff and coordinated through the National Cattlemen's Beef Association.

Institutional Review Board Statement: The study was conducted according to the guidelines of the Declaration of Helsinki, and approved by the Institutional Review Board of Oregon State University (Study Number IRB-2021-0976, 31 March 2021).

Informed Consent Statement: Informed consent was obtained from all subjects involved in the study.

Data Availability Statement: Anonymized data are available from the corresponding author upon request. 
Acknowledgments: We are grateful for the helpful input of four anonymous peer reviewers, feedback on early drafts by Katie Epstein and Clare Kazanski, and the thoughtful contributions of our fifteen interviewees.

Conflicts of Interest: The authors declare no conflict of interest. The funders had no role in the design of the study; in the collection, analyses, or interpretation of data; in the writing of the manuscript; or in the decision to publish the results.

\section{References}

1. Purvis, B.; Mao, Y.; Robinson, D. Three pillars of sustainability: In search of conceptual origins. Sustain. Sci. 2019, 14, 681-695. [CrossRef]

2. Axelsson, R.; Angelstam, P.; Degerman, E.; Teitelbaum, S.; Andersson, K.; Elbakidze, M.; Drotz, M.K. Social and cultural sustainability: Criteria, indicators, verifier variables for measurement and maps for visualization to support planning. Ambio 2013, 42, 215-228. [CrossRef]

3. Åhman, H. Social sustainability—Society at the intersection of development and maintenance. Local Environ. 2013, 18, 1153-1166. [CrossRef]

4. Boström, M. A missing pillar? Challenges in theorizing and practicing social sustainability: Introduction to the special issue. Sustain. Sci. Pract. Policy 2012, 8, 3-14. [CrossRef]

5. Eizenberg, E.; Jabareen, Y. Social sustainability: A new conceptual framework. Sustainability 2017, 9, 68. [CrossRef]

6. Janker, J.; Mann, S. Understanding the social dimension of sustainability in agriculture: A critical review of sustainability assessment tools. Environ. Dev. Sustain. 2020, 22, 1671-1691. [CrossRef]

7. Murphy, K. The social pillar of sustainable development: A literature review and framework for policy analysis. Sustain. Sci. Pr. Policy 2012, 8, 15-29. [CrossRef]

8. Vallance, S.; Perkins, H.C.; Dixon, J.E. What is social sustainability? A clarification of concepts. Geoforum 2011, 42, 342-348. [CrossRef]

9. Baldwin, C.; King, R. Social Sustainability, Climate Resilience and Community-Based Urban Development: What about the People? 1st ed.; Routledge: London, UK; New York, NY, USA, 2018; ISBN 978-1-351-10332-9.

10. Dempsey, N.; Bramley, G.; Power, S.; Brown, C. The social dimension of sustainable development: Defining urban social sustainability. Sustain. Dev. 2011, 19, 289-300. [CrossRef]

11. Magis, K. Community resilience: An indicator of social sustainability. Soc. Nat. Resour. 2010, 23, 401-416. [CrossRef]

12. Manzi, T.; Lucas, K.; Jones, T.L.; Allen, J. Social Sustainability in Urban Areas: Communities, Connectivity and the Urban Fabric; Routledge: London, UK, 2010; ISBN 978-1-84407-674-1.

13. Medved, P.; Kim, J.I.; Ursic, M. The urban social sustainability paradigm in northeast Asia and Europe: A comparative study of sustainable urban areas from South Korea, China, Germany and Sweden. Int. Rev. Spat. Plan. Sustain. Dev. 2020, 8, 16-37. [CrossRef]

14. Twisselman, K. Dietary Guidelines Play Crucial Role for Americans-National Cattlemen's Beef Association. 2020. Available online: https:/ / www.ncba.org/ncba-news/news-releases/news/details/26143/search.aspx (accessed on 8 July 2021).

15. U.S.Department of Agriculture-Cattle and Beef Sector at a Glance. 2021. Available online: https:/ /www.ers.usda.gov/topics/ animal-products / cattle-beef/sector-at-a-glance/ (accessed on 8 July 2021).

16. Cattlemen's Beef Board and National Cattlemen's Beef Association-2017 Cattlemen's Stewardship Review. 2017. Available online: https: / / www.beefitswhatsfordinner.com/Media/BIWFD/Docs/beef-csr-report-2017-final.pdf (accessed on 8 July 2021).

17. Pennsylvania Beef Quality Assurance-History of BQA. Available online: https://www.pa-bqa.org/about/history-of-bqa\#: \{\}: text $=$ In $\% 201982 \% 2 C \% 20$ the $\% 20$ United\%20States, Beef\%20Quality\%20Assurance\%20(BQA) (accessed on 8 July 2021).

18. Ahlering, M.A.; Kazanski, C.; Lendrum, P.E.; Borrelli, P.; Burnidge, W.; Clark, L.; Ellis, C.; Gadzia, K.; Gelbard, J.; Gennet, S.; et al. A synthesis of ranch-level sustainability indicators for land Mmanagers and to communicate across the U.S. beef supply chain. Rangel. Ecol. Manag. 2021, 79, 217-230. [CrossRef]

19. Western Australian Council of Social Service Inc. Focus on the Future: Opportunities for Sustainability in Western Australia. 2002 Available online: http:/ / st1.asflib.net/MEDIA/ASF-CD/ASF-M-00173/submissions/WACOSS.pdf (accessed on 8 July 2021).

20. Beef, It's What's for Dinner-Beef Sustainability: Environmental, Social \& Economic Impact. Available online: https://www. beefitswhatsfordinner.com/raising-beef/beef-sustainability (accessed on 8 July 2021).

21. Kindy, K. After 200 meat plant workers die of Covid-19, OSHA Iisues two fines. The Washington Post, 2020. Available online: https:/ / www.washingtonpost.com/national/osha-covid-meat-plant-fines/2020/09/13/1dca3e14-f395-11ea-bc45-e5d4 8ab44b9f_story.html(accessed on 8 July 2021).

22. Urquhart, J. Oregon standoff ends after 41 days with dramatic surrender. Reuters, 2016. Available online: https://www.reuters com/article/us-oregon-militia/oregon-standoff-ends-after-41-days-with-dramatic-surrender-idUSKCN0VK05F(accessed on 8 July 2021).

23. Baker, M. Amid historic drought, a new water war in the West. The New York Times, 2021. Available online: https://www.nytimes. com/2021/06/01/us/klamath-oregon-water-drought-bundy.html(accessed on 8 July 2021).

24. USC Libraries. Types of Literature Reviews. Available online: https://libguides.usc.edu/writingguide/literaturereview (accessed on 13 September 2021). 
25. Bernard, H.R. Research Methods in Anthropology: Qualitative and Quantitative Approaches, 4th ed.; AltaMira Press: Lanham, MD, USA, 2006; ISBN 978-0-7591-0868-4.

26. Bruno, J.E.; Jamsranjav, C.; Jablonski, K.E.; Dosamantes, E.G.; Wilmer, H.; Fernández-Giménez, M.E. The landscape of North American rangeland social science: A systematic map. Rangel. Ecol. Manag. 2019, 73, 181-193. [CrossRef]

27. Patton, M.Q. Qualitative Research and Evaluation Methods; Sage Publications Inc.: Thousand Oaks, CA, USA, 2002.

28. Janker, J.; Mann, S.; Rist, S. Social sustainability in agriculture-A system-based framework. J. Rural. Stud. 2019, 65, 32-42. [CrossRef]

29. Shreck, A.; Getz, C.; Feenstra, G. Social sustainability, farm labor, and organic agriculture: Findings from an exploratory analysis. Agric. Hum. Values 2006, 23, 439-449. [CrossRef]

30. Guthman, J.; Barbour, M. (En)gendering exposure: Pregnant farmworkers and the inadequacy of pesticide notification. J. Polit. Ecol. 2018, 25, 332-349. [CrossRef]

31. Medland, L. Working for social sustainability: Insights from a Spanish organic production enclave. Agroecol. Sustain. Food Syst. 2016, 40, 1133-1156. [CrossRef]

32. Molinero-Gerbeau, Y.; López-Sala, A.; Șerban, M. On the social sustainability of industrial agriculture dependent on migrant workers: Romanian workers in Spain's seasonal agriculture. Sustainability 2021, 13, 1062. [CrossRef]

33. Gómez, E.G.; Aznar-Sánchez, J.A.; Pérez-Mesa, J.C. Sustainability dimensions related to agricultural-based development: The experience of 50 years of intensive farming in Almería (Spain). Int. J. Agric. Sustain. 2013, 11, 125-143. [CrossRef]

34. Manos, B.; Bournaris, T.; Chatzinikolaou, P. Impact assessment of CAP policies on social sustainability in rural areas: An application in northern Greece. Oper. Res. 2011, 11, 77-92. [CrossRef]

35. Leslie, I.S.; Wypler, J.; Bell, M.M. Relational agriculture: Gender, sexuality, and sustainability in U.S. farming. Soc. Nat. Resour. 2019, 32, 853-874. [CrossRef]

36. Cavicchioli, D.; Bertoni, D.; Pretolani, R. Farm succession at a crossroads: The interaction among farm characteristics, labour market conditions, and gender and birth order effects. J. Rural. Stud. 2018, 61, 73-83. [CrossRef]

37. Campbell, H.; Bell, M.M.; Finney, M. (Eds.) Country Boys: Masculinity and Rural Life; Penn State University Press: State College, PA, USA, 2006.

38. Little, J. Rural geography: Rural gender identity and the performance of masculinity and femininity in the countryside. Prog. Hum. Geogr. 2002, 26, 665-670. [CrossRef]

39. Graddy-Lovelace, G. The coloniality of US agricultural policy: Articulating agrarian (in) justice. J. Peasant. Stud. 2017, 44, 78-99. [CrossRef]

40. McCutcheon, P. Fannie Lou Hamer's freedom farms and Black agrarian geographies. Antipode 2019, 51, 207-224. [CrossRef]

41. Ramírez, M.M. The elusive inclusive: Black food geographies and racialized food spaces. Antipode 2015, 47, 748-769. [CrossRef]

42. Reese, A.M. "We will not perish; We're going to keep flourishing": Race, food access, and geographies of self-reliance. Antipode 2018, 50, 407-424. [CrossRef]

43. de Wit, M.M. What grows from a pandemic? Toward an abolitionist agroecology. J. Peasant. Stud. 2021, 48, 99-136. [CrossRef]

44. Akee, R. Land titles and dispossession: Allotment on American Indian reservations. J. Econ. Race Policy 2019, 3, 123-143. [CrossRef]

45. Johnson, M.K.; Lien, A.M.; Sherman, N.R.; López-Hoffman, L. Barriers to PES programs in Indigenous communities: A lesson in land tenure insecurity from the Hopi Indian Reservation. Ecosyst. Serv. 2018, 32, 62-69. [CrossRef]

46. Equal Justice Initiative. One Million Black Families in the South Have Lost their Farms. 2019. Available online: https: / / eji.org/news/one-million-Black-families-have-lost-their-farms / (accessed on 13 September 2021).

47. Preibisch, K.; Hennebry, J. Temporary migration, chronic effects: The health of international migrant workers in Canada: Table 1. Can. Med. Assoc. J. 2011, 183, 1033-1038. [CrossRef] [PubMed]

48. Getz, C.; Brown, S.; Shreck, A. Class politics and agricultural exceptionalism in California's organic agriculture movement. Polit. Soc. 2008, 36, 478-507. [CrossRef]

49. McLaughlin, J.; McLaughlin, J.; Weiler, A.M.; Weiler, A.M. Migrant agricultural workers in local and global contexts: Toward a better life? J. Agrar. Chang. 2017, 17, 630-638. [CrossRef]

50. Weiler, A.M.; Otero, G.; Wittman, H. Rock stars and bad apples: Moral economies of alternative food networks and precarious farm work regimes. Antipode 2016, 48, 1140-1162. [CrossRef]

51. Arvidsson Segerkvist, K.; Hansson, H.; Sonesson, U.; Gunnarsson, S. A systematic mapping of current literature on sustainability at farm-level in beef and lamb meat production. Sustainability 2021, 13, 2488. [CrossRef]

52. Rivera-Huerta, A.; Lozano, M.D.L.S.R.; Padilla-Rivera, A.; Güereca, L.P. Social sustainability assessment in livestock production: A social life cycle assessment approach. Sustainability 2019, 11, 4419. [CrossRef]

53. Painter, L.; Nallar, R.; Fleytas, M.D.C.; Loayza, O.; Reinaga, A.; Villalba, L. Reconciliation of cattle ranching with biodiversity and social inclusion objectives in large private properties in Paraguay and collective Indigenous lands in Bolivia. Agric. Syst. 2020, 184, 102861. [CrossRef]

54. Gosnell, H.; Gill, N.; Voyer, M. Transformational adaptation on the farm: Processes of change and persistence in transitions to 'climate-smart' regenerative agriculture. Glob. Environ. Chang. 2019, 59, 101965. [CrossRef]

55. Gosnell, H. Regenerating soil, regenerating soul: An integral approach to understanding agricultural transformation. Sustain. Sci. 2021, 1-18. [CrossRef] 
56. Gosnell, H.; Grimm, K.; Goldstein, B.E. A half century of Holistic Management: What does the evidence reveal? Agric. Hum. Values 2020, 37, 849-867. [CrossRef]

57. Gosnell, H.; Charnley, S.; Stanley, P. Climate change mitigation as a co-benefit of regenerative ranching: Insights from Australia and the United States. Interface Focus 2020, 10, 20200027. [CrossRef]

58. Gosnell, H.; Haggerty, J.H.; Travis, W. Ranchland ownership change in the Greater Yellowstone Ecosystem, 1990-2001: Implications for conservation. Soc. Nat. Resour. 2006, 19, 743-758. [CrossRef]

59. Gosnell, H.; Haggerty, J.H.; Byorth, P.A. Ranch ownership change and new approaches to water resource management in southwestern Montana: Implications for fisheries. JAWRA J. Am. Water Resour. Assoc. 2007, 43, 990-1003. [CrossRef]

60. Epstein, K.; Haggerty, J.H.; Gosnell, H. Super-rich landowners in social-ecological systems: Opportunities in affective political ecology and life course perspectives. Geoforum 2019, 105, 206-209. [CrossRef]

61. Epstein, K.; Haggerty, J.H.; Gosnell, H. With, not for, money: Ranch management trajectories of the super-rich in Greater Yellowstone. Ann. Am. Assoc. Geogr. 2021, in press.

62. Wilmer, H.; Fernández-Giménez, M.E. Voices of change: Narratives from ranching women of the southwestern United States. Rangel. Ecol. Manag. 2016, 69, 150-158. [CrossRef]

63. Wilmer, H.; Fernández-Giménez, M.E. Some years you live like a coyote: Gendered practices of cultural resilience in working rangeland landscapes. Ambio 2016, 45, 363-372. [CrossRef]

64. Elliot, V.; Hagel, L.; Dosman, J.A.; Rana, M.; Lawson, J.; Marlenga, B.; Trask, C.; Pickett, W. Resilience of farm women working the third shift. J. Agromed. 2018, 23, 70-77. [CrossRef]

65. Losada-Espinosa, N.; La Lama, G.C.M.-D.; Estévez-Moreno, L.X. Stockpeople and animal welfare: Compatibilities, contradictions, and unresolved ethical dilemmas. J. Agric. Environ. Ethics 2020, 33, 71-92. [CrossRef]

66. Asem-Hiablie, S.; Rotz, C.A.; Stout, R.; Stackhouse-Lawson, K. Management characteristics of beef cattle production in the northern plains and midwest regions of the United States. Prof. Anim. Sci. 2016, 32, 736-749. [CrossRef]

67. de Vries, M.; van Middelaar, C.; De Boer, I. Comparing environmental impacts of beef production systems: A review of Life Cycle Assessments. Livest. Sci. 2015, 178, 279-288. [CrossRef]

68. Garrido, S. Social Life-Cycle Assessment: An introduction. In Reference Module in Earth Systems and Environmental Sciences; Elsevier: Burlington, MA, USA, 2017; ISBN 978-0-12-409548-9.

69. U.S. Roundtable for Sustainable Beef (USRSB). U.S. Beef Industry Sustainability Framework. 2019. Available online: https: //www.beefsustainability.us/Media/SustainableBeef/Docs/master_030220_framework_final.pdf (accessed on 8 July 2021).

70. Blakemore, E. How the GI Bill's Promise Was Denied to a Million Black WWII Veterans. Available online: https:/ /www.history. $\mathrm{com} /$ news / gi-bill-black-wwii-veterans-benefits (accessed on 8 July 2021).

71. Boogaard, B.; Boekhorst, L.; Oosting, S.; Sørensen, J.T. Socio-cultural sustainability of pig production: Citizen perceptions in the Netherlands and Denmark. Livest. Sci. 2011, 140, 189-200. [CrossRef] 